\title{
Dialoškost v sodobni slovenski poeziji: vpeljava persone kot vidik zunanje dialoškosti
}

Varja Balžalorsky Antić

Filozofska fakulteta Univerze v Ljubljani, Oddelek za primerjalno književnost in literarno teorijo, Aškerčeva 2, 1000 Ljubliana, Slovenija https://orcid.org/0000-0003-1411-6226

bvarja@gmail.com

Članek je uvod v širše zasnovano raziskavo o artikulaciji in konfiguraciji subjektov v najsodobnejši slovenski poeziji. Po kratkem povzetku vrst dialoškosti pri Bahtinu in sklepih iz ponovnega branja Bahtinovih tez o monološkosti poezije sledi predstavitev njegove tipologije dialoških odnosov v prozi z vidika prenovljenega pojma lirskega subjekta. Drugi del periodizira krepitev dialoškosti $v$ sodobni slovenski poeziji pri avtoricah in avtorjih različnih generacij. Razlika je med dialoškimi strategijami v strukturaciji pesemskega diskurza in subjekta oziroma subjektov na različnih pesemskih ravneh ( $t$. govorne strategije in pozicioniranja izjavnih subjektov) in, na drugi strani, uprizarjanjem razpada trdnih pojmovanj (filozofske kategorije) subjekta ali (sociološke kategorije) individuuma znotraj monoloških pesniških postopkov. Z vidika pesniških strategij in vidika rekonceptualiziranega lirskega subjekta se novejši pojavi dialoškosti na ravni pesmi v večji meri pogosto vgrajujejo v navidezni monološki model subjektne konfiguracije: mnoštvenost pesemskega subjekta se uveljavlja predvsem na ravni sistema pesniške knjige, manj pa na ravni mikrosistema pesmi ali celo same izjave. Zato je mogoče govoriti o močnem toku zunanje dialoškosti. Sklepna analiza petih zbirk predstavi pojav, ki bi ga glede na Bahtinovo tipologijo lahko uvrstili $v$ zunanji tip dvoglasne besede: vpeljavo pesmi s persono oziroma pesemskih knjig s persono (Oblak in gora Iva Svetine, Opus quinque dierum Taje Kramberger, Izganjalci smisla Milana Dekleve, Trpljenje mlade Hane Katje Gorečan, Hemingwayeve ustnice Krištofa Dovjaka).

Ključne besede: slovenska poezija / Bahtin, Mihail / lirski subjekt / persona / dialoškost / Svetina, Ivo / Kramberger, Taja / Dekleva, Milan / Gorečan, Katja / Dovjak, Krištof 
Članek predstavlja del širše zasnovane raziskave o artikulaciji in konfiguraciji subjektov v najsodobnejši slovenski poeziji. ${ }^{1}$ Posebne pozornosti je deležna proučitev oblik dialoškosti, izrazite in pogoste $\mathrm{v}$ več pesniških generacijah in raznolikih poetikah. Najprej bom razvrstila pojave, ki bi jih lahko označili s krovnim pojmom dialoškosti, nato pa podrobneje obravnavala eno od oblik dialoškosti - koncept persone. Pojav dialoškosti v moderni slovenski poeziji sicer ni novost, a obenem zaradi zgodovinskosti vsakega diskurza vendarle tudi je, saj posamična oblika dialoškosti v odnosu do zunajliterarne resničnosti trenutka svojega nastanka dobi nov predznak. Opazno je, da so se poetike bolj ali manj urbanega intimizma in vsakdana s prvoosebno avtorsko lirsko persono, ki so od devetdesetih let prejšnjega stoletja tvorile prevladujočo in cenjeno strujo slovenskega pesništva, izčrpale. Sodobne transformacije sveta in občutljivosti od poezije terjajo, da prevpraša možnost in smiselnost izrekanja iz ustaljenih izjavnih pozicij.

$\mathrm{V}$ teoretičnem uvodu bom najprej povzela Bahtinove vrste dialoškosti (za podrobnejšo obravnavo glej Balžalorsky Antić, "Bahtin«) in njegovo tipologijo dialoških odnosov v prozi ter zgoščeno predstavila svoj predlog prenovitve pojma lirskega subjekt. Uporaba nekaterih naratoloških pojmov, prenesenih $\mathrm{v}$ obravnavo lirike, na primer koncepta fokalizacije, implicitnega avtorja ali zunaj frankofonskega okolja manj znanega koncepta recitativa (H. Meschonnic, glej Balžalorsky Antić, Lirski), namreč drugače osvetli pesniške postopke, ki se vpisujejo $\mathrm{v}$ krovni pojem dialoškosti.

\section{Vidiki Bahtinove dialoškosti in tipologija dialoških odnosov}

Ko izrečemo besedo dialoškost, seveda najprej pomislimo na Mihaila Bahtina in njegovo teorijo. Obenem se spomnimo, da je prav Bahtin podal slovite teze o monološkosti lirike. Te sicer niso Bahtinov izum, temveč so značilne za skoraj vse starejše in moderne teorije, koreninijo pa v romantični teoriji lirike. Bahtin najbolj nadrobno postulira monološkost lirike, ki jo v drobcih sicer omenja tudi v drugih delih, denimo v Problemih poetike Dostojevskega (1963) (glej npr. Bahtin, Problemi 225), v znamenitem spisu Beseda v poeziji, beseda v romanu, ki je nastal med letoma 1934-1935 in bil objavljen šele leta 1972 (Bahtin,

${ }^{1}$ Razprava je nastala v okviru raziskovalnega projekta "Slovenska literatura in družbene spremembe: nacionalna država, demokratizacija in tranzicijska navzkrižja» (J6-8259), ki ga je sofinancirala Javna agencija za raziskovalno dejavnost Republike Slovenije iz državnega proračuna. 
Estetika 57-77). Toda topos o ptolemejski enotnosti ter zlitosti jezika in monolitne subjektivitete v poeziji je značilen zgolj za ta segment njegovega opusa in je $\mathrm{v}$ protislovju $\mathrm{z}$ njegovo teorijo splošne dialoškosti. $\mathrm{Na}$ tem mestu ne gre za to, da bi znova osvetljevali že dobro znano notranjo paradoksnost Bahtinovega opusa (Skaza 355; Javornik 383). ${ }^{2}$ Podrobnejša proučitev pokaže, da so Bahtinove teze o monološkosti poezije v nasprotju z njegovo splošno teorijo dialoških odnosov v literaturi in govorici nasploh, kakor jih je razvijal deloma že v zgodnejših, zlasti pa v poznejših spisih. Po Bahtinu je dialoškost pojav, značilen za vsak diskurz, vsako izjavo, tudi pesemsko. Bahtin pa dokončno konceptualizacijo izpelje šele v spisih, nastalih po spisu Beseda v poeziji, beseda $v$ romanu, kjer govori o monološkosti lirike, zato ta razsežnost $\mathrm{v}$ njem ni prisotna. V Bahtinovem opusu dialoškost torej zajema več ravni:

1. Dialoškost $\mathrm{v}$ najširšem smislu pomeni intersubjektivno naravo govorice, s katero Bahtin postavi temelj koncepciji diskurza kot nasprotja jezika. Ta konceptualizacija diskurza se ujema $s$ poznejšo Benvenistovo: tako Bahtin kot Benveniste uvidita, da ima vsako besedilo dve ravni oziroma plasti; da sicer je jezik, a tudi več kot jezikovni sistem znakov (Bahtin, Estetika 289; Benveniste 63). V omenjenem spisu o monološkosti lirike ta vidik ni upoštevan, Bahtin obravnava pesniški jezik in ne diskurz poezije, pesemsko izjavo. Pomemben vidik te konceptualizacije dialoškosti je pojem glasu ali gledǐ̌čne točke, ki pa v Benvenistovi teoriji diskurza umanjka. V splošno lingvistiko ta pojem prenese šele Oswald Ducrot, ko na podlagi Bahtinove teorije razvije koncept izjavljalca, ki bolj ali manj ustreza naratološkima pojmoma fokalizacije in perspektive (Ducrot 181-215).

2. Estetska dialoškost, dialoškost estetskega dogodka, ki predpostavlja t. i. trasgredientnost avtorja glede na junaka. Znotraj estetskega dogodka se dialogiziranje ne dogaja le na ravni (subjektov) teksta in subjekta - interpreta, temveč mora slednji (tudi v liriki, glej Bahtin, Estetika 185-191) stopiti v dialog z najmanj dvema diskurzivnima instancama teksta kot »korelativnih dejavnikov umetniške celote« (Bahtin, Estetika 20), ki sta prav tako v dialoškem odnosu in ju Bahtin imenuje avtor in junak. Ta različnost dveh

${ }^{2}$ Bahtinova teorija je bila od osemdesetih let zelo prisotna v slovenski literarni vedi (npr. poleg Skaze in Javornika glej vsaj še Škulj, „Dialogizem «; Juvan, »Parodija«, Literarna; Verč, "Izjava«; Zabukovec, »Bahtinov«; Habjan, Janus). V pričujoči izpeljavi povzemam svoje ponovno branje Bahtinovih tez o poeziji na ozadju Benvenistove teorije diskurza; klasifikacijo dialoškosti deloma izpeljujem tudi iz doslejšnjih dognjanj navedenih avtorjev, zlasti Škulj, »Dialogizem» in Juvan, "Parodija»9-10. 
diskurzivnih instanc temelji na »občem obrazcu temeljnega estetsko produktivnega razmerja, na intenzivnem zunajbivanju avtorja v odnosu do junaka" (Bahtin, Estetika 22). Posledica tega uvida je sorodna posledici uvida o splošni dialoškosti v govorici, namreč o večplastnosti vsake izjave, razdeljeni na izjavljanje, ki je diskurzivna raven avtorja, in izjavo, ki je diskurzivna raven junaka. Avtor in junak sta, kot vidimo, tako diskurzivni instanci, ki sta ekvivalentni Benvenistovima subjektu izjavljanja in subjektu izjave.

2. Dialoškost v smislu raznojezičja, skupka raznolikih sociolektov, idiolektov, jezikovnih stilov itd., ki naj bi bilo, kot zatrjuje Bahtin v spisu Beseda v poeziji, beseda v romanu, značilno zlasti za roman, ne ali manj pa za poezijo.

3. Dialoškost ustroja subjekta; razsrediščenost, procesualnost subjekta in intersubjektivni temelj subjektivizacije, ki ga Bahtin v zgodnjih filozofsko-antropoloških tekstih ( $K$ filozofiji dogodka, 1918, Avtor in junak v estetski dejavnosti, 1920-24?) povezuje $s$ filozofijo dogodka, in sicer na podlagi pojmov jaz-za sebe, jaz-za drugega in zunajbivanja. Kot ugotavlja Aleksander Skaza, ta uvid temelji na kritiki monolitnega razumevanja človeka (Skaza 360). Dialoškost tako predpostavlja koncepcijo razsrediščene zavesti (Škulj 37). Škulj tudi opozarja na Bahtinov uvid o neustreznosti kartezijanske koncepcije subjekta kot cogita in navaja Bahtinovo izjavo: "Jaz je tok izjav«. Ta definicija se v spisu z močnim marksističnim predznakom Beseda $v$ življenju in beseda v poeziji Bahtina/Vološinova iz leta 1926 zaostri v opredelitev zavesti kot ideološkega pojava in proizvoda družbenega občevanja (Bahtin/ Vološinov 212), pri čemer je sleherni akt zavesti razumljen kot notranji govor, tok besed, intonacij in vrednotenj in posledično že kot družbeno dejanje.

Pri raziskavi sodobne poezije bom upoštevala vse vidike dialoškosti. Prvi in drugi vidik sta vpisana v moje teoretsko izhodišče; pesem pojmujem kot diskurz, ki je vselej dvoravninski, tudi sam subjekt v diskurzu se izraža dvojno, kot subjekt izjavljanja (pri Bahtinu avtor kot diskurzivna instanca, glej zgoraj) in subjekt izjave (pri Bahtinu junak kot diskurzivna instanca). Tej dvoravninskosti se pridružuje še množica mogočih subjektnih pozicij na različnih ravneh diskurza. Ta vidik je posebej okrepljen v literaturi kot umetniškem diskurzu.

Praktično-analitično tipologijo dialoških postopkov poda Bahtin v delu Problemi poetike Dostojevskega (1963). Izhodišče klasifikacije je ugotovitev metalingvistike, da je sleherni govor lahko usmerjen bodisi 
na svoj predmet bodisi tujo besedo, lahko pa tudi na oboje hkrati. V zadnjem primeru gre za dvojno usmerjene besede. Po daljši obravnavi (Bahtin, Problemi 205-230) izpelje Bahtin abstraktno klasifikacijo (224-225, glej tudi Zabukovec 323-324), pri čemer opozori na dinamičnost odnosov do t. i. tuje besede v konkretnih realizacijah, ki lahko hkrati pripadejo tudi različnim tipom in podtipom.

I. Prvi tip je premi, neposredno na svoj predmet usmerjeni govor (tj. govor, ki sporoča, izraža, upodablja, sporoča). Ta je oblikovan monološko, kar pomeni, da vanj ne vdira nobena oblika tuje besede, ki bi ostala nepodrejena avtorjevi poziciji.

II. Drugi tip predstavlja govor upodobljenih likov. Tudi ta ima neposreden, na predmet usmerjen pomen, vendar se ne nahaja na isti ravni kot avtorjev govor; njegova enotnost je kljub različnim stopnjam objektnosti vselej podrejena "poslednji smiselni instanci«, tj. "nalogam avtorjevega konteksta (Bahtin, Problemi 212). Prva tipa sodita med enoglasne besede.

III. Šele tretji tip diskurza je dvoglasen, tj. naravnan na »tujo besedo«. Zajema tri podtipe:

1. Pri prvem avtorjeva pozicija v tuji govor sicer prodre, vendar z njim ne prihaja $\mathrm{v}$ konflikt, temveč sledi njegovi lastni smeri. Ker pride do zlitja glasov (Bahtin, Problemi 223), gre za enosmerno dvoglasno besedo. Kot značilne oblike tega podtipa navaja Bahtin stilizacijo, pripovedovalčevo pripoved in prvoosebno pripoved.

2. Pri t. i. raznosmernem tipu pride do notranje dialogizacije; avtor $\mathrm{v}$ tuji govor vloži svojo pozicijo, ki je nasprotna in ga primora, da se ji podredi. Značilen primer raznosmerne besede je parodični govor.

3. Zadnji tip je t. i. aktivni tip oziroma zrcaljena beseda. Avtor tuje besede ne vključi v svojo, je ne reproducira, a v svojem govoru vseeno skrivaj referira nanjo (»če ne bi bilo reakcije na mišljeno tujo besedo, bi bila celotna struktura govora popolnoma drugačna", Bahtin, Problemi 220). S tujo besedo se avtorjeva beseda $\mathrm{v}$ tem tipu spoprijema takorekoč v samem predmetu, zato ga je včasih težko razbrati. Ta vrsta je izjemnega pomena za literarni govor, še posebej velik pomen ima $\mathrm{v}$ avtobiografskih žanrih in nasploh $\mathrm{v}$ prvoosebnih izpovednih pripovedih s polemično noto. Vpliv tujega govora se v aktivnem tipu lahko odrazi v strukturaciji govora na različnih ravneh (intonacija, sintaksa, stil idr.) 
Poudariti velja, da se Bahtin ukvarja z vrstami "prozne besede«, torej njegova klasifikacija zajema izključno pripovedništvo. Avtor obenem ugotavlja, da "pesniška beseda $\mathrm{v}$ ožjem pomenu zahteva enoličnost besed, zvaja jih na en skupni imenovalec, pri čemer ta imenovalec lahko sodi bodisi med besede prvega tipa bodisi med nekatere oslabljene podvrst drugih tipov« (Bahtin, Problemi 225). Tudi v Problemih torej ne odstopa od ugotovitev v spisu Beseda v poeziji, beseda v romanu, kjer govori o monolitnosti pesniškega jezika, stila in zavesti. Vendar podobno kot v tem spisu, nato tudi v Problemih svojo ugotovitev na koncu relativizira, rekoč, da

so tudi v poeziji mogoča dela, ki ne zvajajo vsega besednega gradiva na en skupni imenovalec, a taka dela so v 19. stoletju izjemno redka in specifična. Mednje bi lahko prišteli, recimo, "prozno" liriko Heineja, Barbiera, deloma Nekrasova in drugih (rezka "prozaizacija» lirike se uveljavi šele v 20. stoletju.) [...] Vendar tudi v poeziji ne moremo rešiti bistvenih vprašanj, če ne upoštevamo zgoraj omenjenega vidika obravnave besede, saj v poeziji različni tipi besed zahtevajo različno stilistično obdelavo. (225)

Spričo tega Bahtinovega opozorila in moje uvodne teze, da se tudi poezija vpisuje $\mathrm{v}$ širšo teorijo dialoškosti (dialoškost same govorice), se zdi upravičeno vprašati, do katere mere bi ta tipologija utegnila koristiti obravnavi strategij pesniške dialoškosti. Spomniti se velja, da je eden ključnih postopkov $\mathrm{v}$ moderni in sodobni poeziji narativizacija in dramatizacija ter (tudi) s tem povezana dialoškost. ${ }^{3}$ Predpostavimo lahko, da so nekateri elementi Bahtinove klasifikacije uporabni tudi za obravnavo dialoškosti v pesmi, vendar šele v povezavi z rekonceptualizacijo osnovnih pojmov lirike, zlasti lirskega subjekta in različnih plasti pesemskega diskurza.

\section{Rekonceptualizacija lirskega subjekta}

$\mathrm{Na}$ temelju Bahtinove teorije dialoških odnosov in njenega prenosa $\mathrm{v}$ lingvistiko pri Oswaldu Ducrotu ter nekaterih drugih referenc (zlasti Émile Benveniste in Henri Meschonnic in nekaterih transnaratoloških pristopov, npr. pri Petru Hühnu) pri raziskavi sodobne slovenske poezije izhajam iz prenovljenega razumevanja lirskega subjekta (glej Balžalorsky Antić, Lirski). Tega pojma ne razumem kot monološko in zgolj govorno instanco, katere govor ni posredovan prek nobene druge

\footnotetext{
${ }^{3} \mathrm{O}$ moderni liriki in narativizaciji glej Pavlič, "Lirika«; zlasti 232-234.
} 
instance, kakor je lirski subjekt razumela tradicionalna literarna teorija, temveč kot mnoštven dispozitiv, ki se v dogodku pesmi konfigurira $\mathrm{v}$ različnih plasteh sistema pesemskega diskurza.

$\mathrm{Z}$ vidika formalne ali literarno-morfološke razplastitve subjektnih instanc v pesemskem diskurzu zato predlagam razlikovanje empiričnega avtorja in empiričnega bralca od različnih diskurzivnih instanc. $\mathrm{Na}$ najvišji diskurzivni ravni se nahaja diskurzivna instanca besedilnega subjekta, ki je pojmovna ustreznica naratološkemu rekonceptualiziranemu implicitnemu avtorju. Gre manj za pozitivno opredeljeno instanco, saj jo mora bralec opredeliti bolj po negativni poti, zlasti prek neujemanj med strukturo besedila in vsebino izjave, t. j. prek besedilnih nekonsistentnosti in protislovij (glej tudi Hühn 152-153). Pomemben aspekt instance besedilnega subjekta je $\mathrm{v}$ moji izpeljavi tudi Meschonnicov recitativ oziroma ritem-subjekt, ki se konfigurira $\mathrm{v}$ čutno-materialni plasti diskurza, v t. i. generaliziranem pomenjanju, ki presega semantično-leksikalni pomen. ${ }^{4} \mathrm{Na}$ naslednji ravni pesemskega diskurza se nahaja subjekt izjavljanja v smislu lirskega glasu, ki ustreza pripovednemu glasu oziroma pripovedovalcu iz teorij pripovedi. $\mathrm{Na}$ ravni pesemske zgodbe ali diegeze, ki je obenem tudi izjavna raven, ki je vselej niže od izjavne ravni subjekta izjavljanja, se nahaja persona, ki je lahko govorec (subjekt izjave) ali ne. Tudi kadar subjekt izjavljanja in subjekt izjave navidezno sovpadata, ju je treba na temelju Benvenistovih spoznanj o njuni različnosti v sleherni izjavi ločevati. V diegezi se lahko konfigurirajo še druga subjektna žarišča, ki ne dobijo nujno učinka osebe niti učinka glasu ter so razpršena v pesemski diegezi in so pogosto nosilci predrefleksivnih-afektivnih elementov (personifikacije, simboli, alegorije, pokrajina itd.). Na vseh ravneh pesemskega diskurza se lahko oblikujejo gledišča, ki so vidik perspektivizacije: ta niso materialni vir govora, ampak žarišča, ki jim je mogoče pripisati zaznavne, spoznavne, psihološke, afektivne, vrednostne procese. Pomembni parametri pri konfiguraciji pesemskega subjekta so tudi čas, različni časovno-krajevni kazalniki in kontaktna smer govora (npr. nagovor).

${ }^{4}$ Navezujoč se na Benvenistovo spoznanje o dvoravninskosti diskurza in o sistemih semantičnega pomenjanja, ki so utemeljeni zgolj na izjavljanju, Meschonnic $\mathrm{v}$ svoji poetiki nadomesti dvojico označenec - označevalec s pojmom pomenjevalca [signifiant], ki je proizvajalec t. i. generaliziranega pomenjanja. Pomenjanje pomeni specifično organizacijo učinkov diskurza, ki niso zvedeni na pomene izjave, temveč jih ustvarja dejavnost besed v izjavljanju, njihova performativna moč. Recitativ kot maksimalna subjektivizacija govorice (Meschonnic, Politique 190) pomeni delovanje govorice preko specifične serialne semantike: ritmične in prozodične paradigmatike, verig pomenjanja $\mathrm{v}$ smislu sosledja konzonantno-vokalnih serij, ki ustvarjajo edinstvene odnose oziroma vrednosti v sistemu pesmi (Meschonnic, Politique 17). 


\section{Dialoškost v sodobni slovenski poeziji: razvrščanje pojavov}

Primož Čučnik (roj. 1971) leta 2007, v času, ko je v slovenski poeziji mogoče zaznavati vse bolj pogosto in raznoliko rabo dialoškosti, v avtopoetskem eseju »Problemi tehnopoetike« zapiše:

Preprosto mislim, da noben enoznačni jaz in/ali zgolj vertikalni subjekt ne more več izraziti sveta $v$ vsej njegovi zapletenosti, jezikovni mnogoznačnosti in živosti vsakdanje govorice ... Svet na ravni jezika doživljam kot mnogoznačno zmes različnih (socialnih, medijskih, "jezikovnih" ...) govoric o svetu, ki si jih predstavljam kot bistvene plasti večpomenskosti. Te govorice in jezike pa prečijo napake, prazna mesta in motnje. (107)

Izjava je primerno izhodišče za premislek o sodobnih pesniških praksah z vidika pesemskega subjekta oziroma subjektov. V navedenih Čučnikovih besedah, ki govorijo o nezmožnosti "stebrastega jaza" (Emily Dickinson), obenem slišimo zelo bahtinovsko intonirane glasove. Vendar, kot smo videli zgoraj, Bahtin s podobnimi, skoraj enakimi besedami ne opiše poezije, temveč raznojezičje $\mathrm{v}$ romanu, ki ga $\mathrm{v}$ tem spisu protipostavlja monolitnosti jezika poezije. Živa dejanskost pesemskih besedil, vsaj od romantike naprej, dokončno pa z nastopom pesniškega modernizma vse bolj radikalno razdira predstave o monološkosti poezije. Pomislimo le na dela Victorja Hugoja, Roberta Browninga, Alfreda Tennysona, Auguste Webster, Julesa Laforguea, Roberta Frosta, T. S. Eliota, Ezre Pounda, Langstona Hughesa, Fernanda Pessoe, Henrija Michauxa, Carol Ann Duffy, če navedemo le najbolj izrazite. Kljub temu v poeziji še vedno prevladuje monološki model, kjer se instance lirske persone, subjekta izjavljanja, izjavljalcev/fokalizatorjev in implicitnega avtorja na videz prekrivajo in s tem ustvarjajo iluzijo spontanega izrekanja in doživljanja (prim. Wolf).

Raziskavo trenutno omejujem na slovensko poezijo med letoma 2000 in 2020, ne da bi težila k celostnemu pregledu, saj izpostavljam le pesniške prakse, ki uporabljajo katerega od dialoških postopkov. ${ }^{5}$ Glede na doslej pregledano gradivo je mogoče ugotoviti, da je različno rabo dialoškosti zaznati pri vseh pesniških generacijah, čeprav so predstavniki generacije, rojene pred letom 1955, manj številni. Strategije dialoškosti, zlasti raba dramskega monologa, so pogoste zlasti v »ženski

${ }^{5} \mathrm{O}$ poliglosiji je prva, v zvezi s poezijo Miklavža Komelja, pisala Alenka Jovanovski, pri čemer je delno izhajala tudi iz Bahtina (glej Jovanovski, »Kako«). Jovanovski temo delno nadaljuje v Jovanovski, »Transformativni«; o poliglosiji pri avtoricah pa v Jovanovski, »Tukaj«. 
pisavi«, t. j. pri avtoricah srednje in mlajše ter najmlajše generacije, zlasti od leta 2011 naprej.

Obdobje 2000-2020 je mogoče z vidika pojavljanja dialoškosti pogojno razmejiti na tri dele: od 2002 (izid Rose Miklavža Komelja) do 2007, ko je mogoče izpostaviti le nekaj pesniških knjig; od 2007 do 2011, ko se pojav intenzivira; od 2011 do 2016, ko se zdi raba - zlasti pri avtoricah - še pogostejša in doseže vrh. Od leta 2016 je vsaj po številu zbirk opaziti pojemanje, z nekaj izstopajočimi izjemami pri oblikah tako zunanje kot notranje dialoškosti.

V izhodišču raziskave velja razmejiti dva vidika dialoškosti:

1. Dialoške strategije v strukturaciji pesemskega diskurza in njenega subjekta oziroma subjektov na različnih pesemskih ravneh ( $\mathrm{t}$. govorne strategije in pozicioniranja izjavnih subjektov);

2. Uprizarjanje razpada trdnih pojmovanj (filozofske kategorije) subjekta ali (sociološke kategorije) individuuma na ravni same "pesemske zgodbe«, in sicer prek motivov in tem po tradicionalni terminologiji ali shem (okvirjev in skript), izotopij in dogodkov, če uporabimo kognitivistično izrazje (glej npr. Hühn).

Ta dva aspekta dialoškosti se lahko pojavljata skupaj ali ločeno. Hevristično bi torej lahko govorili o strukturnem in vsebinskem vidiku, čeprav to ne pomeni, da pristajamo na ločevanje vsebine in oblike. V pesmi z vsaj na videz povsem tradicionalnim modelom lirskega subjekta je tako mogoče na ravni pesemske zgodbe diagnosticirati problematizacijo subjekta, ne da bi pri tem pesem prek svoje strukturacije to tudi udejanjala na drugih ravneh. Predpostavljam, da so najbolj celostni in relevantni - ne zgolj v umetniškem smislu, pač pa tudi z vidika transformativnih etično-spoznavnih in družbenih potencialov tisti primeri pesmi, zbirk in opusov, kjer se udejanjata oba vidika dialoškosti. Pri razdelavi dialoških strategij v strukturaciji pesemskega diskurza je mogoče uporabiti tako po Bahtinu prilagojeno tipologijo dialoških odnosov kakor tudi prenovljeni pogled na subjekt v pesmi. $\mathrm{Na}$ strukturni ravni velja poleg tega ločevati še med zunanjo dialoškostjo, ki zajema pojav zunanjega dialoga, pesem vložnico oziroma dramski monolog in uvedbo negovoreče persone, in notranjo dialoškostjo, kjer je mogoče opaziti različne oblike bahtinovske dvoglasne besede znotraj strukturno navidezno monološkega govora, torej tako raznosmerno dvoglasno besedo kot aktivni tip dvoglasne besede. V tem primeru sta na ravni subjektne konfiguracije kot prenove lirskega subjekta ključni kategoriji fokalizacije in perspektivizacije. 


\begin{tabular}{|c|c|c|c|c|c|c|c|c|c|c|c|c|}
\hline 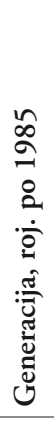 & & & 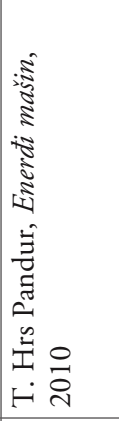 & & 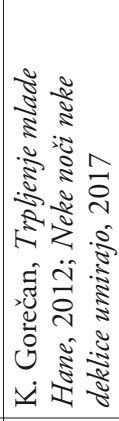 & 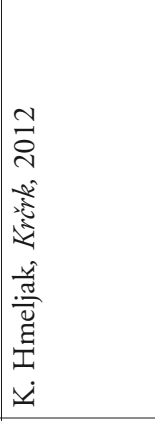 & 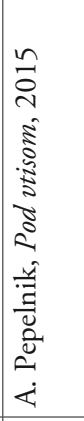 & 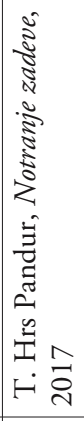 & 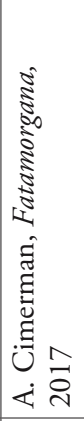 & 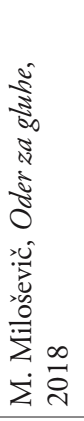 & 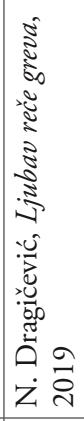 & 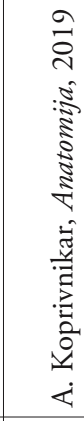 \\
\hline 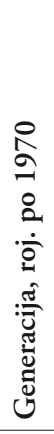 & 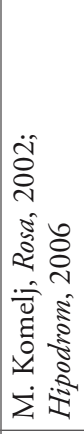 & 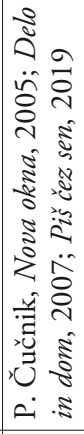 & 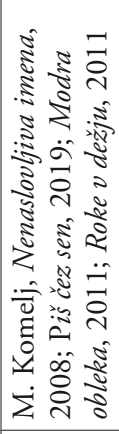 & 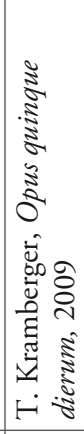 & 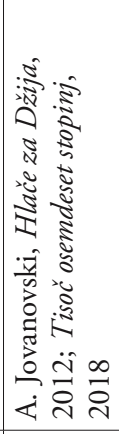 & 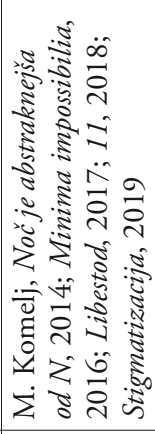 & 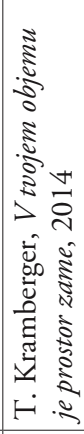 & 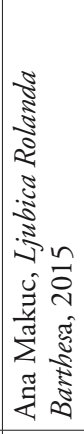 & 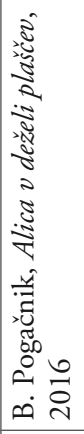 & 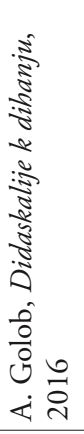 & 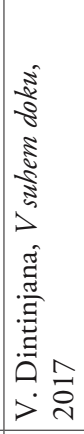 & 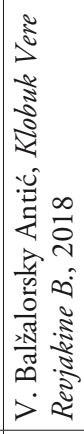 \\
\hline 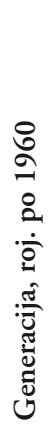 & 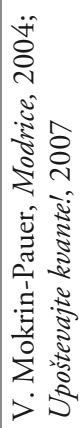 & & 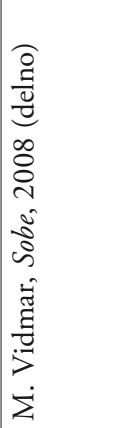 & & 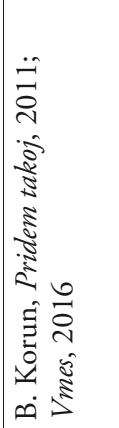 & 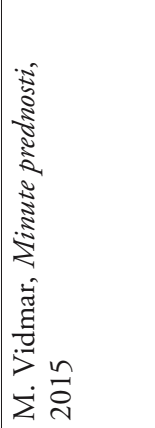 & 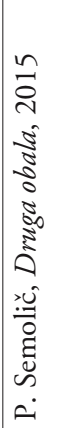 & 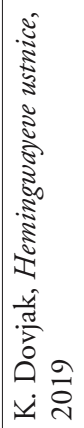 & 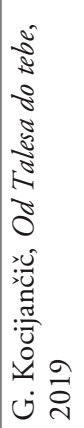 & & & \\
\hline 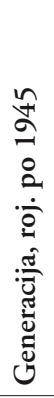 & 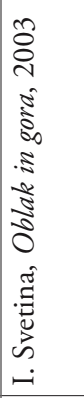 & 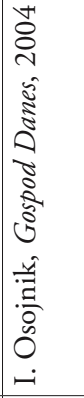 & 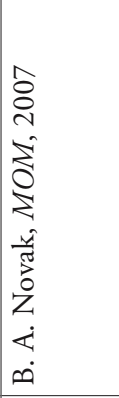 & & 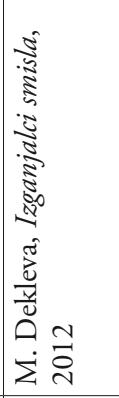 & 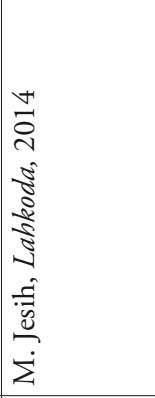 & 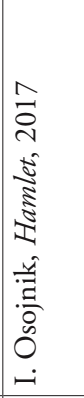 & 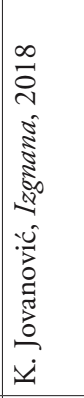 & & & & \\
\hline & 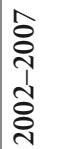 & & 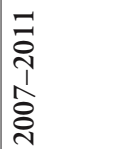 & & 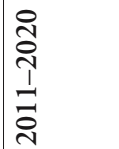 & & & & & & & \\
\hline
\end{tabular}




\section{Confession vs. confection}

Današnja slovenska poezija povečini sodi $\mathrm{v}$ tradicionalno naravnani mainstream postpostmodernih poetik malih zgodb in nestabilne subjektivitete, radikalnejše eksperimentiranje je bilo donedavna redko, z nekaj pomembnimi izjemami, denimo poezijo Miklavža Komelja, ki je nato občutno vplivala tudi na najmlajšo pesniško generacijo. Pri tej je opaziti pluralizacijo poetik in postopen, a vse bolj izrazit povratek $\mathrm{k}$ modernističnim pa tudi avantgardističnim zgledom, kar vpliva tudi na subjektno konfiguracijo. V tem oziru velja omeniti Muanisa Sinanovića, Jana Krmelja, Uroša Praha, v zadnjem času pa Nino Dragičević, Urško Kramberger, Sergeja Harlamova in Nado Kavčič. Kljub tem premikom je še vedno razširjen tradicionalni, navidezno monološki model subjektne konfiguracije $\mathrm{z}$ avtorsko figurirano lirsko persono, tj. jazom, ki je največkrat neproblematizirano izenačen $s$ pesnikom ali pesnico, pretanjene avtobiografske reference in reference na znan kontekst pa so pomembni gradniki pesemskega sveta. Še vedno je opazna postmodernemu stanju prilagojena izpovedno-pripovedna lirika, in sicer v vseh pesniških generacijah in poetikah: Peter Semolič, Uroš Zupan, Maja Vidmar, Marcello Potocco, Katja Perat, Ana Pepelnik, Jure Jakob, Tibor Hrs Pandur, Kaja Teržan idr.

To ne pomeni, da se confection (oblikovanost) in confession (izpovednost), če uporabim posrečena angleška izraza, izključujeta. Že tradicija dramskega monologa, ki v slovenski poeziji zlasti od leta 2011 prvič doživlja resnični razcvet, ne izključuje izpovedne razsežnosti, čeprav gre za vpeljavo izmišljenega, fiktivnega lika. $\mathrm{V}$ isti pesniški knjigi se pesmi z očitnimi avtobiografskimi elementi kombinirajo $s$ pesmimi $s$ fiktivnimi (ali zgodovinskimi) liki. Poseben primer je knjiga Pod vtisom Ane Pepelnik, ki jo tvorijo izključno verzi drugih pesnikov (moškega spola), v posamezne pesmi pa so povezani na način specifičnega readymade, tako da so moška obrazila subjekta izjave spremenjena v ženska, s čimer pesmi oblikujejo ženski lik in govorko; ustvarjalna-umetniško gesta poleg intervencije "drugega spola» sestoji iz konstruiranja že obstoječih verzov v (novo) pesem. Pesmi z razvidno žensko osebo kljub izključni uporabi tehnik pastišizacije, kolažiranja in montaže ustvarjajo vtis skrajne confession singularnega izkustva, kar je v skladu s siceršnjo avtoričino poetiko.

Tudi raba postopka persone pogosto sproži igro zrcal med avtorsko obarvanim govorcem-pripovedovalcem in eno ali več upodobljenimi personami. Tak »jaz je drugi« je zaznaven denimo v zbirki Gospod Danes Iztoka Osojnika in knjigi Iva Svetine Oblak in gora. Igra 
zrcaljenj med jazom in drugim oziroma različnimi ravnmi jaza v konfiguraciji pesemskega diskurza je izrazita tudi v knjigi Trpljenje mlade Hane Katje Gorečan. Najnovejša zbirka Primoža Čučnika Piš čez sen (2019) si za osrednjo, izrazito avtorefleksivno in avtopoetično temo izbere prav problematizacijo jazov zunaj in znotraj pesmi ter njunih kompleksnih odnosov na različnih stopnjah drugosti. Postajanje, prehajanje, nedokončnost in nedokončanost $\mathrm{v}$ povezavi s performativno močjo pesmi kot prostora neskončne svobode izrišejo fluiden, a obenem izrazito samozavedajoč se subjekt, ki vsakič postane novi drugi, tako da se otrese identitete ("prešel sem v cvetenje", "samo piš sem", $31)$ in se levi v druge (tudi živalske in rastlinske) entitete: "vživi se v jablano« (17), »katera rastlina sem« (24), »moj pravi jaz listi trave« (38), »bil sem vrabec« (42), "vedno sem tudi ptič živčnega spreletanja» (84). Osrednji cikel knjige kot odmev na Whitmanove Pesmi o sebi tvorijo Pesmi o osebi, ki že z naslovom opozarjajo na konstruiranost pesemskih jazov, motto zbirke pa so verzi Emily Dickinson: „Kadar govorim o sebi / kot zastopnici pesmi, / s tem ne mislim na sebe, temveč umišljeno osebo«. V nadaljevanju se bom posvetila prav tisti obliki zunanje dialoškosti, ki poeziji dokončno izmakne izrecni avtorski "jaz« in ga nadomesti s fiktivnim likom, čeprav se prvi, kot rečeno, lahko še vedno skriva izza maske (persone).

\section{Persona ... in "pesemski romani«}

Uporaba persone, ki se $\mathrm{v}$ moderni liriki kot konsistenten postopek pojavi v Poundovi knjigi Personae (1909), ima izvore v viktorijanskem dramskem monologu in je pravzaprav njegova zgodovinska variacija. S pojmom persona se je zgodnja modernistična lirika hotela tudi konceptualno distancirati od avtorsko oblikovanega lirskega subjekta. Posebne obravnave je bil pojem, v povezavi s t. i. objektivnim korelativom, deležen pri Eliotu, anglosaksonsko novo kritištvo pa je pojem nato preneslo tudi v literarno teorijo (glej tudi Pavlič, "Lirika» 228). ${ }^{6} \mathrm{~V}$ okviru analize sodobne poezije, ki uporablja dialoške strategije, se mi zdi smiselno razlikovati žanr dramskega monologa, če uporabimo izraz iz anglofone literarnovedne tradicije, ali vložnice, če izhajam iz nemške, od postopka vpeljave (fiktivne) persone, in sicer vsaj z dveh vidikov. $\mathrm{Z}$ vidika izjavne

${ }^{6}$ Podobno se je v nemškem okolju zgodilo s t. i. lyrisches Ich: prva ga je teoretizirala Margarete Susman, vendar je spodbuda, enako kot v anglosaksonskem kontekstu, prišla od pesnikov simbolističnega krožka, zbranega okrog Stefana Georgeja (glej Balžalorsky, Lirski 60). 
pozicije je pri dramskem monologu lik namreč nujno tudi govorec, ki mora imeti v izvorni različici žanra tudi naslovnika. Nasprotno pa v pesmih $s$ persono liku ni nujno podeljen glas, s čimer se znotraj takih pesmi vidneje vzpostavlja raven subjekta izjavljanja kot govorca, včasih tako, da se na ekstradiegetični ravni oblikuje tudi »oseba» tega govorca, ki vdira na nižjo raven, ta oseba pa je lahko vidneje povezana tudi z empirično osebo avtorja. Kot produkta dveh različnih zgodovinskih formacij se klasični (viktorijanski) dramski monolog in (modernistična) raba person razlikujeta $\mathrm{v}$ načinu izgradnje identitete lika in obenem seveda tudi pesemskega diskurza. Prvi je veliko bolj osredotočen na psihologijo lika, ki si jo prizadeva čimbolj natančno in jedrnato razkriti skozi govor lika, čigar identiteta je pogosto povezana $\mathrm{z}$ družbenokritično razsežnostjo pesmi, še posebej pri pesnicah, denimo pri Augusti Webster ali Feliciji Hermans. V modernističnih pesmih s persono - paradigmatična primera sta Eliotov Ljubezenski spev J. Alfreda Prufrocka in Poundov Hugh Selwyn Mauberley - pa je identiteta persone nestabilna, negotova, razsrediščena, $\mathrm{k}$ čemur pripomorejo različne strategije decentriranja govora (različni vidiki dialoškosti, preskakovanje fokalizacije in glavne izjavne pozicije med različnimi pesemskimi ravninami) in posameznih mikroravni pesemske zgodbe (npr. parameter prostorsko-časovne umeščenosti). To je sicer le modernistični okvir, znotraj katerega vznikne postopek persone. Sodobna raba strategije se od njega največkrat občutno oddaljuje in se zaradi povezovanja $s$ postopkom narativizacije zelo približa dramskemu monologu, saj navadno podaja določen izsek iz življenja persone, katere psihološke poteze so koherentno in zaokroženo predstavljene, čeprav ne gre za pravi "monolog«.

Konsistentno vpeljevanje postopka persone je pri nekaterih slovenskih pesnikih prisotna že pred letom 2000. Posamične pesmi s persono velja razlikovati od pesniških knjig s persono, $\mathrm{v}$ katerih se $\mathrm{v}$ več pesmih pojavlja(jo) isti lik(i). Ponekod se $\mathrm{v}$ knjigah $\mathrm{z}$ istim likom izmenjujejo pesmi s persono (brez glasu ali le z drobci izjav) in pravi dramski monologi ter dialogi; taki sta denimo knjigi Taje Kramberger Opus quinque dierum (2009) in Druga obala Petra Semoliča (2015), v manjši meri pa tudi zbirka Barbare Pogačnik Alica v deželi plaščev (2016). V nadaljevanju bom kratko predstavila pet knjig s persono oziroma personami.

Leta 2003 je izšla knjiga Iva Svetine Oblakingora s podnaslovom Yüan Hung-Tao: 1568-1610. V njej avtor v sto enajst pesmih v prozi upesni dneve starodavnega kitajskega pesnika. Naslovna pojma sta za zbirko bistvena na več ravneh, saj predstavljata dve plasti življenja; oblak spremenljivost in minljivost vsakdana, gora pa brezčasno trdnost nekaterih vselej veljavnih resnic. Narava oblakov in gora pa je v zbirki vključena 
tudi $\mathrm{v}$ formalno zgradbo besedil, saj imajo ta načeloma dvojno strukturo, v enem delu govorijo o Yüanovih vsakokratnih osebnih zaznavah in mislih, v drugem pa je strnjena modrost, spoznana preko vsakdanjih nadrobnosti, pa naj gre za opazovanja leta ptice, pitje čaja itn. To dvojnost upošteva tudi instanca pripovedovalca, predvsem na ravni časovnosti. Pripovedovanje iz prevladujoče retrospektive prehaja v simultanost, da bi poudarilo veljavnost misli v vsakem trenutku, tudi v trenutku bralčeve sedanjosti. Ločila za označevanje premega govora so v zbirki namenoma nedosledna - nikoli ne vemo zares, kdo je tisti, ki govori: ali je to sam Yüan ali pripovedovalec njegove besede povzema ali celo bere iz knjige. Ambivalentnost pri določevanju fokalizatorja je prisotna zlasti pri intimnih doživetih in miselnih uvidih, ob katerih se zdi, da fokalizacija ne teče skozi persono, ampak je fokalizator sam pripovedovalec oziroma gre za vzpostavitev dvojnosti gledišča. Gre za igriv preplet različnih subjektnih instanc - pripovedovalca, junaka in gledišča, ki preskakuje z diegetične ravnine na ekstradiegetično, $s$ tem pa se poigrava z dinamizacijo med pripovedovanjem, ki predvideva dvoplastnost (raven pripovedovanja in raven zgodbe), in pesniškim izjavljanjem, ki je tradicionalno razumljeno kot enoplastno (lirski govorec kot edini origo besedila).

Zbirka Opus quinue dierum Taje Kramberger, objavljena leta 2009, je prelomna tako glede dialoškosti, zlasti večglasja, kakor glede premikov znotraj t. i. »ženske pisave« proti izraziteje izraženim feminističnim stališčem. Gre za dokumentaristično grajen pesemski mozaik o Dreyfusovi aferi. Ta je v knjigi razumljena kot paradigmatski dogodek evropske družbe in hkrati "simptom vseh pobebavljenih režimov" (Kramberger, Opus 11). Kot taka pa je spoznana kot še vedno delujoča $\mathrm{v}$ sedanjosti, pa tudi vedno znova vznikajoča v preoblekah simbolnega in fizičnega nasilja. Pesniško razkrivanje simbolnih dominacij (nasilje proti vsem zatiranim, izničenim, ženskam, živalim, zamolčanim, obrobnežem vseh vrst) in boj proti njim pesnici pomeni razčiščevanje temeljev v boju za "preobrazbo družbenega sveta» (57). V knjigi ta boj avtorica poveže s strategijo dialoškosti, ki podpira tudi kompozicijo knjige, razdeljeno na cikle, ki časovno preskakujejo iz obdobja Dreyfusove afere v avtoričino sodobnost. Skozi zbirko, ki v pesniško govorico programsko vnaša znanstveni diskurz, tako srečujemo znane in manj znane, večini bralcev (poezije) pa tudi neznane zgodovinske osebnosti, vpletene v Dreyfusovo afero. Nekateri liki se pojavljajo kot govorci celotnih pesmi (Zola, Kraus, brat Alfreda Dreyfusa) ali celo ciklov (Dreyfus v ciklu Hudičev otok), gre torej za dramske monologe. $\mathrm{O}$ drugih likih, ki so polarizirani na "pozitivne« in "negativne«, pa 
govori pripovedovalka na višji pesemski ravni, ki je pogosto označena s potezami empirične avtorice. Ta bolj ali manj očitno vdira na raven pesemske zgodbe z vrednostnimi avtorskimi komentarji, $s$ časovnimi navezavami na sodobnost in na kolektivni subjekt "nas" ali pa z referencami na svoje lastno življenje.

Milan Dekleva je že pred letom 2000, spodnjo časovno mejo te raziskave, v zbirki Panični človek (1990) izbral predsokratskega misleca Anaksimandra za osrednji lik in govorca celotne pesniške knjige. Pesnik v knjigi Izganjalci smisla, objavljeni leta 2012, svojo značilno poetiko soočanja miselno-filozofskih in kulturnih tradicij Vzhoda in Zahoda, obenem pa tudi pesništva in filozofije izostril z izrazito dialogizacijo (teh tradicij) na ravni knjige. Zbirko namreč sestavlja 58 pesmi o treh zgodovinskih osebnostih iz tradicije Vzhoda in Zahoda: pesnica Sapfo, daoististični modrec Lao $\mathrm{Zi}$ in predsokratski filozof Heraklit. Te osebe v pesmih govorijo, se pogovarjajo ali pa o njih govori govorec višje pesemske ravnine. Protagonisti zbirke torej tkejo dolg, razdrobljen pogovor $\mathrm{s}$ številnimi digresijami. Tako $\mathrm{v}$ govoru posameznega govorca kot na ravni celotne zbirke se prepletajo diskurzi vsakdana sodobnosti, znanosti, filozofije in poezije. Posebnost pesniškega obstoja treh person je njihova transzgodovinskost: obstajajo v vseh časih, vsak v svojem, obenem pa tudi ali predvsem $\mathrm{v}$ (naši) sodobnosti (med aktualnimi referencami najdemo Srebrenico, Černobil, Osamo bin Ladna, Obamo, hotmail, nogometaša Messija itd.). ${ }^{7}$

Leta 2012 je izšla tudi knjiga Katje Gorečan (1989) Trpljenje mlade Hane. Že naslov aludira na Goethejev roman, slovenski bralec pa v njem prepozna tudi aluzijo na osebo iz drame Slavka Gruma Dogodek $v$ mestu Gogi. Knjiga predstavlja avtoironizacijo izpovednega intimističnega modela poezije $\mathrm{z}$ osrediščenim lirskim jazom. Te se loti $\mathrm{z}$ jasno vzpostavitvijo dveh pesemskih ravnin - izjavne in zgodbene, $s$ tem pa tudi dveh subjektov, pripovedovalke in junakinje. Govorici inherentno razliko med subjektom izjavljanja in subjektom izjave torej knjiga kvalitativno izkoristi $\mathrm{v}$ smeri jasnejše dialogizacije $\mathrm{z}$ močno narativno strukturacijo. $Z$ nizanjem slogovno namerno okorno upovedenih dogodkov iz intimnega, deloma pa tudi javnega življenja junakinje Hane (»ženskega otroka«, kot junakinjo v eni od pesmi naslovi "slovenski moški parnas ${ }^{8}$ ), ustvari (avto)ironične krhlje nekakšnega »Bildungsromana" o mladi, postajajoči umetnici. Vanj vplete močno

${ }^{7} \mathrm{Ob}$ tem velja opozoriti, da se transzgodovinskost pojavlja še pri I. Svetini, T. Kramberger in K. Dovjaku. Še posebej je zanimivo, da se pri vseh povezuje z dialoškostjo.

${ }^{8}$ Aluzija na nesorazmerno večjo zastopanost moških v slovenskem pesniškem kanonu. 
motivno-tematsko izotopijo različnih vidikov telesnosti, zlasti seksualnosti iz dekliške in ženske perspektive, ki je namerno podana z distanciranega, banaliziranega in mestoma infantiliziranega gledišča. Verjetno ključna referenca te zbirke se eksplicitno pojavi v eni od pesmi, kjer junakinja prebira roman E. Jelinek Ljubimki. $\mathrm{Na}$ avstrijsko nobelovko se knjiga ne navezuje le z uporabo upovedovalnih postopkov, predvsem t. i. distanciranega pripovedovanja v odnosu pripovedovalke do junakinje, ampak se na roman Ljubimki tudi tematsko navezuje z obravnavo ženskosti v zakotnem, duhovno provincialnem okolju. Obenem humoren, na površini lahkoten in banaliziran slog brez težav beremo tudi kot poskus ironične vpeljave žanra chick lit (tipa Dnevnik Bridget Jones) $\mathrm{z}$ namenom razbijanja visokega pesniškega registra. Slike z naslovi, ki obenem spominjajo na dvodelne naslove otroških slikanic ali risank na način ime glavnega junaka + dogodek, ki se mu zgodi (Hana in svet, Hana in menstruacija, Hana in britje, Hana in anoreksija, Hana in penisi, Hana in masturbiranje), se ves čas izrisujejo kot dinamičen odnosa med govorko, ki pogosto prevzema tudi predpostavljeno stališče skupnosti, in neprilagojeno junakinjo. Ta dinamika se giblje med distanciranjem in identifikacijo prek različnih emotivnih in vrednostnih odnosov, od posmehovanja in obsojanja do (redkejšega) sočustvovanja. Ta igra se izraža s pogosto menjavo fokalizacij, z vrinjenimi indirektnimi izjavami junakinje, dosledno pisanimi v kurzivi, in metaleptičnimi vdori z ene pesemske ravnine na drugo, do katerih pride bodisi na ravni pesmi ali pa samo v posameznem odseku ali celo izjavi. V zadnjem primeru gre za eksplicitno dialoško dinamizacijo stavka, kjer glasova/gledišči/ravnini pripovedovalke in junakinje trčita in se tisto, kar je bilo prej izraženo le skozi notranjo fokalizacijo, tudi »uglasi«, s tem ko vdre na slovnično raven: "hana se smrti ne bojim" (Gorečan, Trpljenje 66), "hana se gibljem v območju minusa (67), "hana ne stremi k izpolnitvi lastne sreče, ampak stremim k izpolnitvi lastne nesreče« (prav tam).

Zbirka Hemingwayeve ustnice (2019) Krištofa Dovjaka za protagonista postavlja ameriškega pisatelja. Podobno kot Dreyfusova afera v zbirki Taje Kramberger Hemingwayevo življenje deluje kot "paradigmatski dogodek« velikega dela 20. stoletja, povezan pa je predvsem s prvo svetovno vojno in njenimi posledicami za duševno individualno in kolektivno fizionomijo desetletij po njej. Ponavljajoči se naslovni motiv ustnic predstavlja sprožilec za vstop v iskanje sočutnega stika s travmami generacije (»most, ki pelje čez / čez samomor, čez čredo, v sočutje, / k Soči«, Dovjak 10) in soočanje s »tragično počasnostjo človeškega duha» 20. stoletja (14). Pomen vélike vojne je razviden že v posvetilu knjige, ki je nastala ob stoti obletnici njenega začetka, transzgodovinskost ozi- 
roma preplet časov, ki se pojavlja tudi pri nekaterih drugih obravnavanih zbirkah, pa je tu navezana na transgeneracijsko povezanost $\mathrm{z}$ (anonimnimi ali imenovanimi) udeleženci vojne. Pesemsko fabulo na ravni zbirke sestavljajo štirje tematsko-motivni prameni: upovedovanje drobcev iz pisateljevega življenja se prepleta s pramenom "pesmi-slik«, ki izpisujejo dialog s Hemingwayevimi fotografijami, zlasti tistimi z lova, v drugem delu knjige pa stopita v ospredje njegovo bivanje v Parizu in roman z avtobiografsko razsežnostjo Sonce tudi vzhaja. Med stranske like se tako zapišejo nekateri Hemingwayevi bližnji (sestra Ursula, soproge, Hadley Richardson, Martha Gelhorn, Pauline Pfeiffer), njegovi sodobniki (Gertrude Stein, Joyce, manekenka Jean Patchett) in junaki iz omenjenega romana. Knjigo otvori pesem Nespečnost (klinika Mayo) o zdravljenju z elektrošoki tik pred pisateljevim samomorom, ki uvede v nadaljevanju prevladujoč upesnjevalni postopek vzpostavljanja identitete glavne persone in hkrati pesemske zgodbe: sintaktično razdrobljenost, prevlado nominalnega stila in veriženje krajših, večinoma metonimičnih sklopov podob. Močno poudarjena je ritmično-pomenska plast, tako v smislu ritma $\mathrm{v}$ ožjem pomenu besede kot $\mathrm{v}$ smislu samoglasniško-soglasniške paradigmatike na ravni sistema posamezne pesmi. Tako se izriše silhueta razdrobljene fabule (ena od pesmi ima avtorefleksivni naslov "fabula rapide"), ki sicer uporabi razpoložljive dokumente o avtorjevem življenju, a poskuša prodreti pod zaokroženost pisateljeve "zgodbe", v nezavedno, ki ga nato, kot se zdi, skuša povezati $s$ kolektivnim nezavednim. Stik s protagonistom in njegovo povezavo z duhom (začetka) 20. stoletja se tako gradi predvsem - rečeno z Deleuzom in Guattarijem - z bloki afektov in perceptov (glej Deleuze in Guattari 168-226). O pisatelju in drugih personah večinoma govori neizražen lirski glas na ravni subjekta izjavljanja, v nekaterih pesmih pa reference izdajajo tudi avtorsko oblikovani subjekt izjavljanja. Zaradi prevladujoče neizraženosti tega lirskega glasu, še posebej v povezavi s strategijo asociativnosti, ima posebno vlogo fokaliziranje, ki preskakuje od zunanje fokalizacije v notranjo in nazaj. Zbirka uvede tudi doslej še neznan postopek: nadpisani tekst, ki med drugim opozarja na razliko med ravnjo izjavljanja in izjave in deluje kot vrivek, komentar subjekta izjavljanja oziroma pripovedovalca na višji diskurzivni ravni, kadar se zdi, da v pesmi prevladuje notranja fokalizacija. 


\section{Sklep}

V preteklih dveh desetletjih se je prevladujoča monološka in enoglasna krajina slovenske poezije precej diverzificirala in vtis je, da ta proces še kar traja. Upehani avtorski jaz, ki je sicer še vedno zelo prisoten, pogosto znotraj ene pesniške knjige sobiva $\mathrm{z}$ drugimi osebami in glasovi. Po najnovejši slovenski poeziji se tako sprehajajo ali v njej celo govorijo Sapfo, Salome, Lao Zi, Heraklit, Mati Tereza, žena Krištofa Kolumba, Hemingway, Ratzinger, Hamlet, Pocahontas, Alica, Monica Levinski, lord Byron in številni drugi. Pridružujejo se jim tudi podganček, polž, rak samotar, kal teloha, škarje in prt. Vznik te polifonije časovno nastopi po daljšem obdobju prevlade narativnosti, ki se je uveljavila v precej poenotenih poetikah postpostmodernizma, ki so temeljile na (urbanih) majhnih zgodbah vsakdana. Ko se ta že dodobra ustaljeni postopek pesemske narativizacije poveže s strategijo dialoškosti, govoreči ali negovoreči personi v posamezni pesmi omogoči hitro dovolj zaokroženo vzpostavitev trdnejše identitete in njene zgodbe. Tukaj obravnavane knjige z uvedbo ene ali več glavnih person (Yüan, Alfred Dreyfus, Sapfo, Heraklit in Lao Zi, Hana, Hemingway) dajejo vtis nekakšnih fragmentiranih pesemskih »romanov", pri čemer seveda ne merimo na žanr romana $\mathrm{v}$ verzih ali romantične pesnitve. Trije med njimi gradijo pesemsko zgodbo na makroravni knjige, tako da postopek narativizacije spremlja tudi bolj ali manj občutna prozaizacija pesemskega govora (Svetinova Oblak in gora, Trpljenje mlade Hane K. Gorečan, v nekoliko manjši meri Opus quinque dierum T. Kramberger) na ritmično-sintaktični ravni, medtem ko se Izganjalci smisla, še bolj pa Hemingwayeve ustnice soočajo $\mathrm{z}$ možnostjo gradnje pesemske fabule na podlagi asociativnosti, razbitosti slike sveta in slike govorice, izraženi s hitrimi preskoki v nizanju podobja in večjo slovnično eliptičnostjo.

\section{VIRI}

Čučnik, Primož. Piš čez sen. Ljubljana: LUD Literatura, 2019.

Dekleva, Milan. Izganjalci smisla Ljubljana: LUD Literatura, 2012.

Dovjak, Krištof. Hemingwayeve ustnice. Ljubljana: KUD Apokalipsa, 2019.

Gorečan, Katja. Trpljenje mlade Hane. Ljubljana: Center za slovensko književnost, 2012.

Kramberger, Taja. Opus quinque dierum. Ljubljana: Center za slovensko književnost, 2009.

Osojnik, Iztok. Gospod Danes. Ljubljana: LUD Literatura, 2004.

Pepelnik, Ana. Pod vtisom. Ljubljana: LUD Šerpa, 2015.

Svetina, Ivo. Oblak in gora. Ljubljana: Študentska založba, 2003. 


\section{LITERATURA}

Bahtin, Mihail. Estetika in humanistične vede. Prev. Helena Biffio et al. Ljubljana: Studia humanitatis, 1999.

Bahtin, Mihail. Problemi poetike Dostojevskega. Prev. Urša Zabukovec. Ljubljana: LUD Literatura, 2007.

Bahtin/Vološinov. "Discours dans la vie et discours dans la poésie "Mikhaïl Bakhtine le principe dialogique suivi d'Écrits du Cercle. Ur. Tzvetan Todorov. Pariz: Seuil, 1982. 181-215.

Balžalorsky Antić, Varja. »Bahtin in Ducrot v perspektivi rekonceptualizacije lirskega subjekta«. Slavistična revija 64.2 (2016): 165-179.

Balžalorsky Antić, Varja. Lirski subjekt. Rekonceptualizacija. Ljubljana: Založba ZRC SAZU, 2019.

Benveniste, Émile. Problemi splošne lingvistike I. Prev. Igor Žagar in Bernard Nežmah. Ljubljana: Studia humanitatis, 1988.

Čučnik, Primož. "Problemi tehnopoetike«. Literatura 190.19 (2007) 99-108.

Ducrot, Oswald. Izrekanje in izrečeno. Prev. Jelica Šumič-Riha. Ljubljana: Studia Humanitatis, 1988.

Deleuze, Gilles in Felix Guattari. Kaj je filozofija? Prev. Stojan Pelko. Ljubljana: Študentska založba, 1999.

Habjan, Jernej. Janus, Prokrust, Bahtin: kvadratura Bahtinovega kroga. Ljubljana: LUD Literatura, 2008.

Hühn, Peter. »Plotting the Lyric«. Theory into Poetry. Ur. Eva Müller-Zettelmann in Margarete Rubik. Amsterdam: Rodopi, 2005. 147-172.

Hurley, Michael D. in Michael O'Neil. Poetic form. An introduction. Cambridge: Cambridge University Press, 2012.

Javornik, Miha. "Nesklenjenost Bahtinove misli kot njena odlika. (Kaj je sploh dialog?)«. Estetika in humanistične vede. Mihail Bahtin (avtor). Ljubljana: Studia Humanitatis, 1999. 383-398.

Jovanovski, Alenka. »Kako govorijo živi: esej o poeziji Miklavža Komelja«. Literatura, 197/198.19 (2007): 175-210.

Jovanovski, Alenka. "Transformativna moč v sodobni slovenski poeziji 2004-2010: fragmenti«. Sodobna slovenska književnost: (1980-2010). Obdobja 29. Ur. A. Zupan Sosič. Ljubljana: Filozofska fakulteta, 2010. 123-129.

Jovanovski, Alenka, »Tukaj in zdaj: reinvencija sodobne ženske poezije». Šestnajst slovenski pesnic: antologija = Szesnaście poetek stoweńskich : antologia. Ur. Tatjana Jamnik, Michal Koczy, Agnieszka Będkowska-Kopczyk. Ljubljana: DSP, 2011.363-378.

Juvan, Marko. "Parodija in Bahtin«. Primerjalna književnost 19.2 (1996): 1-28.

Juvan, Marko. Intertekstualnost. Ljubljana: DZS, 2000.

Juvan, Marko. Literarna veda v rekonstrukciji. Ljubljana: LUD Literatura, 2006.

Meschonnic, Henri. Le Signe et le poème. Pariz: Gallimard, 1975.

Meschonnic, Henri. Critique du rythme: anthropologie historique du langage. Lagrasse: Verdier, 1982.

Meschonnic, Henri. Politique du rythme: politique du sujet. Lagrasse: Verdier, 1995.

Pavlič, Darja. "Lirika z vidika univerzalnosti pripovedi«. Primerjalna književnosti 37. 3. (2014): 227-238.

Müller-Zettelmann, Eva in Margarete Rubik, ur. Theory Into Poetry. Amsterdam: Rodopi, 2005.

Skaza, Aleksander. "Estetski humanizem Mihaila Bahtina". Estetika in humanistične vede. Mihail Bahtin (avtor). Ljubljana: Studia Humanitatis, 1999. 355-382. 
Škulj, Jola. "Dialogizem kot nefinalizirani koncept resnice: literatura 20. stoletja in njena logika inkonkluzivnosti«. Primerjalna književnost 19.2 (1996): 37-48.

Wolf, Werner. "Aesthetic Illusion in Lyric Poetry?«. Poetica 30.3/4 (1998): 251-89.

Zabukovec, Urša. "Bahtinov Dostojevski«. Problemi poetike Dostojevskega. Bahtin, Mihail (avtor). Prev. Urša Zabukovec. Ljubljana: LUD Literatura, 2007. 309331.

Verč, Ivan. "Izjava kot vprašanje kulturne evolucije«. Primerjalna književnost 19.2. (1996): 29-36.

\section{Dialogism in Contemporary Slovenian Poetry: Persona Poems and Persona Collections as an Aspect of External Dialogism}

Keywords: Slovenian poetry / Bakhtin, Mikhail / lyrical subject / persona / dialogism / Svetina, Ivo / Kramberger, Taja / Dekleva, Milan / Gorečan, Katja / Dovjak, Krištof

This article presents an introduction into a broader project that deals with the articulation and configuration of subjects in contemporary Slovenian poetry. In the theoretical part, I provide a brief outline of the different aspects and forms of dialogism defined by Mikhail Bakhtin and propose some conclusions reached after my re-reading of Bakhtin's thoughts on the monologic nature of poetry. In the empirical section, I situate the chronological landmarks of the increased use of dialogism in recent Slovenian poetry and list the key authors involved. An introductory difference is made between the dialogic strategies that concern the structuration of the poetic discourse and its subjects on different levels of discourse (the speaking positions and the position of the enunciative subject) on the one hand, and representations of the decomposition of the "hard" conceptions of the (philosophical) category of the subject and/or the (sociological) category of the individual by using monological procedures in the structuration of the poem on the other. From the standpoint of poetic strategies, recent phenomena of dialogism on the level of the poem are often incorporated into the apparent monologic model of the subject configuration: the plurality of the poetic subject is introduced foremost in the macro-system of the book and less in the micro-system of the poem or even the utterance. The remainder of the paper presents one of the two aspects of external dialogism that, according to Bakhtin's typology, would be considered the external type of the two-voiced word: the introduction of the persona poem. In the end, a short analysis of five poetry collections is provided (Ivo Svetina's The Cloud 
and the Mountain, Taja Kramberger's Opus quinque dierum, Milan Dekleva's The Exorcists of Sense, Katja Gorečan's The Sorrows of Young Hana, and Krištof Dovjak's Hemingway's Lips).

1.01 Izvirni znanstveni članek / Original scientific article UDK 821.163.6.09-1

DOI: https://doi.org/10.3986/pkn.v43.i2.06 